\title{
The impact of economic growth on technological developments, emoneys and fluctuations interest rates and exchange rates in Indonesia
}

\author{
Milla Naeruz $^{1 *}$,Syaad Afiffudin ${ }^{2}$, Dede Ruslan ${ }^{3}$, and Muhammad Syafii ${ }^{4}$ \\ ${ }^{1}$ Universitas Sumatera Utara 1 (Medan, Sumatera Utara, Indonesia) \\ ${ }^{2}$ Universitas Sumatera Utara 2 (Medan, Sumatera Utara, Indonesia). \\ ${ }^{3}$ Universitas Negeri Medan 3 (Medan, Sumatera Utara, Indonesia). \\ ${ }^{4}$ Universitas Sumatera Utara 4 (Medan, Sumatera Utara, Indonesia)
}

\begin{abstract}
Technological developments have an impact on the payment system, namely Electronic Money moved very fast in 2018 and 2019 , in 2018 it was $50.3 \%$ of the money in circulation and economic growth increased by $5.4 \%$ even though the interest rate in that year was at $6 \%$. This means that some Indonesians have started to make changes to the payment system. Changes in digitalization in the financial sector, especially with new fundamental changes in the behavior of people's lives from the social and economic fields. The concept of Financial Technology is very good in the formation of digital financial infrastructure based on sustainable technological innovations that are considered effective in financial markets, including for small and medium-sized companies, this article focuses on three factors that affect economic growth, namely capital, labor, and technological developments. This study uses secondary time series data for the 2004-2019 quarter using Multiple Regression (OLS/One Least Square) and processed using the eviews 10 application. This study aims to determine the impact of technology on economic growth. And the results show that Emoney has a negative and significant effect on economic growth, interest rates and exchange rates have a negative effect on economic growth, and technology has a positive effect on economic growth.
\end{abstract}

\section{Introduction}

Technology is growing faster in the future, judging by the system of its use. Technology is a means or system that functions to provide comfort and convenience for humans. It is very clear that technology has changed the economic system, especially in terms of transactions and payments, which used to be done manually, now they are done online. It is highly probable that this change will affect the financial system of Bank and Non-Bank Financial Institutions as well as society in general. Technology makes it easier for people to send money and other transactions online using their mobile phones. This tool seems more convenient than physically transferring cash (Mccaffrey \& Schiff, 2017). Advanced technology can significantly affect lifestyle changes, especially in rural areas (Wilson \& Edwards, 2008). Keynessian Roy F. Harrod and Evsey D. Domar focus on economic growth functions such as capital, demand, and investment, and are the most important factors for economic improvement in a country. The New Economic growth theory was developed by Robert Lucas and Paul Romer. Where this theory focuses its cycle on human resources which are the main capital for increasing production and the national economy. According to Lucas and Romer, a workforce with broad knowledge, higher education, and professional training can accelerate the development of industry and technology. As a result, national production activities can be increased more quickly.

Table 1. Indonesian Community Activities in Using the Internet.

\begin{tabular}{|l|l|l|}
\hline Year & $\begin{array}{l}\text { User Internet } \\
\text { (Juta) }\end{array}$ & $\begin{array}{l}\text { Online } \\
\text { Transaction } \\
\text { (Rp. Triliun) }\end{array}$ \\
\hline 2017 & 143 & 30.942 \\
\hline 2018 & 154 & 77.766 \\
\hline 2019 & 196.7 & 182.02 \\
\hline
\end{tabular}

Source: APJII.co.id

From the data above, according to the Association of Indonesian Internet Service Providers, from 2017 to 2019 Indonesia is one of the countries with the most internet users and has experienced a significant increase from year to year. Online transactions obtained from 2017 to 2019 continue to increase, meaning that the Indonesian nation is a developing country that is participating in the digitization process. Because the Indonesian people have started to make changes to transactions from offline to online and the internet is considered a very important thing. Technological developments have an influence on the growth of e-

* Corresponding author: milla.naeruz@gmail.com 
commerce, especially in 3 important parts of the Indonesian economy, employment, public spending levels, and regional economic growth which will be discussed further in the discussion below based on McKinsey \& Company $(2018,2020)$.

Table 2. Macro Indicator.

\begin{tabular}{|l|l|l|l|}
\hline Year & $\begin{array}{l}\text { Economic } \\
\text { Growth (\%) }\end{array}$ & $\begin{array}{l}\text { Internet } \\
\text { User (Juta } \\
\text { jiwa) }\end{array}$ & $\begin{array}{l}\text { EMoney } \\
\text { Growth (Rp. } \\
\text { Triliun) }\end{array}$ \\
\hline 2015 & 4.8 & $\mathbf{8 8}$ & $\mathbf{5 3 5 . 6}$ \\
\hline 2016 & 5.0 & 132.7 & 683.1 \\
\hline 2017 & 5.1 & 143 & 943.3 \\
\hline 2018 & 5.4 & 171.6 & $\mathbf{2 9 0 0}$ \\
\hline 2019 & 5.02 & 196.7 & $\mathbf{2 7 0 0}$ \\
\hline
\end{tabular}

Source: BPS

(McKinsey \& Company, 2020) stated that technological developments will affect economic growth, employment and spending levels and based on macro data from the Central Statistics Agency, it shows that technological developments will affect Indonesia's macro economy, including economic growth, Electronic Money growth. in 2018 economic growth was 5.4\% down $5.02 \%$ but internet users rose to 196.7 million people from 171.6 million people while emoney growth fell from 2700 trillion rupiah in 2019 from 2900 trillion rupiah

Table 3. Changes in Interest Rates and Exchange Rates

\begin{tabular}{|l|l|l|l|}
\multicolumn{5}{|c}{ from. } \\
\hline $\begin{array}{l}\text { Item } \\
\begin{array}{l}\text { Economic } \\
\text { Growth }\end{array}\end{array}$ & $5.1 \%$ & $5.4 \%$ & $5.02 \%$ \\
\hline Interest rate & $4.25 \%$ & $6 \%$ & $5 \%$ \\
\hline $\begin{array}{l}\text { Exchanges } \\
\text { rate (Rp-US\$) }\end{array}$ & $\mathrm{Rp} .13 .548$ & $\mathrm{Rp} .14 .481$ & $\mathrm{Rp} .13 .901$ \\
\hline
\end{tabular}

Source : BPS

based on the data above, economic growth fluctuated from 2017 to 2019, where in 2018 the highest economic growth was $5.4 \%$. while the interest rate was also the highest in 2018 at $6 \%$, the exchange rate was also the same at 14,481 rupiah against the dollar. This means that based on 2018 if economic growth increases, interest rates and exchange rates will also increase, or in other words two indicators that are very influential on economic growth in Indonesia are interest rates and exchange rates

The development of Financial Technology contributes to economic growth through the financial sector, namely increasing e-commerce and financing the real sector as well as creating profitable loans for small and medium enterprises (Sadigov, Vasilyeva, \& Rubanov, 2020). If the rupiah exchange rate decreases, the government will implement a policy to reduce the amount of rupiah in circulation, namely by increasing the value of the rupiah through raising interest rates, so that the law of supply and demand balance can be achieved (Mankiw, 2006). Mobile technology, the Internet and all digital currencies have a strong influence on the demand for money. So it can be concluded that financial technology and monetary policy have a high role in the economy of a nation (Mumtaz \& Smith, 2020)

\subsection{Problem Statement}

Technological developments have triggered an increase in the number of internet users and along with that, digital payment users have also increased. This change caused economic growth to fluctuate from $4.80 \%$ in 2015 to $5.02 \%$ in 2019 . Not only economic growth, interest rates and exchange rates also had an impact on this change. Harrod Domar focuses on the function of economic growth, namely demand and investment capital, while Romer focuses on economic growth on capital, namely human resources who have knowledge and insight. the findings of mumtaz Financial technology and monetary policy have a significant effect on the economy of a nation, especially in controlling the financial system on the stock market, sadigov and friends state that the development of financial technology contributes to economic growth in the financial sector, especially the increase in ecommerce turnover and real sector financing..

\subsection{Formulation Problem}

Based on the introduction above, it can be obtained a problem statement, namely Do Electronic Money, Interest Rates, Exchange Rates and Technology (internet users) affect Economic Growth?

\subsection{Research Purposes}

To analyze, test, develop and modify the theory or previous research on the effect of Electronic Money, Interest Rates and Exchange Rates and Technology (internet users), on Economic Growth whether partially or completely accepted either in changes or in the development of modifications.

\section{Literatue Review}

\subsection{Economic Growth}

Robert M Solow argued that developing or underdeveloped countries in improving the economy by increasing the accumulation of physical capital, labor and human resources as well as efficiency in their use. The role of technology has not been seen as a driving force for economic growth. so that if a failure is found in the development process, it can be resolved by placing an efficient investment allocation. because the sollow theory states that to increase savings and investment it will directly increase resources this will affect the output obtained. and will continuously affect the improvement of the economy of a nation (Mankiw: 2000). $\mathrm{Y}=\mathrm{A} K \alpha \mathrm{L} \beta$

Where

$\mathrm{Y}=$ Aggregate output

$\mathrm{L}=$ Number of workers

$\mathrm{K}=$ Total capital 
$\mathrm{A}=$ Multifactor productivity or total factor productivity $=$ Elasticity of capital output

$=$ Elasticity of labor output

Roy Harrod (1948) and Evsey Domar (1957 Harrod and Domar use Keynes's thinking that the development process in the long run will affect the level of savings and the level of investment through economic growth. Harrod-Domar theory concludes that economic growth is determined by high savings and investment. If savings and investment are low, the economic growth of the community or country will be low. or in other words Harrod focused on saving and investment as an important factor in economic growth.

\subsection{Technology}

Technology comes from the Greek Technologia which means systematic treatment or handling something systematically, while techne as the basis of the word technology means skill or expertise, skills and knowledge. The word technology is often understood by ordinary people as something in the form of a machine or things related to machinery.

Technology according to Roger is an action design tool that reduces uncertainty with a causal relationship in achieving a desired result. While the opinion of Jacques Ellul defines technology as a whole method that rationally leads and has efficient characteristics in every human activity.

Gary J Anglin argues that technology is the application of the behavioral and natural sciences and other knowledge in a systematic and systematic way to solve problems. Meanwhile, according to Vaza technology is a process carried out in an effort to realize something rationally.

Technology is at the center of changing payment arrangements, with better solutions and capabilities influencing consumer behavior and expectations, also driving considerable industry transformation (Broom, 2015). The most common approach used to measure the impact of the digital economy is the technology that is included in the regulation of the production function Van Reenen, Draca, and Sadun (2007).

\subsection{Emoney}

Electronic Money has an insignificant positive effect on economic growth (Pitriani Ritonga 2018). In the 21 st century, non-cash payments are considered a very practical and convenient means of payment and are considered as alternative payments from cash. Plastic money is considered more practical because it is more convenient and safe in everyday life in its use (JapanMETI, 2017). The increase in people's use of non-cash transactions is driven by the ease of transactions which can encourage a decrease in transaction costs and in time will stimulate economic growth. In addition to making transactions easier It is hoped that in the future non-cash transactions can reduce the circulation of money from the central bank, where this will affect the central bank's task in controlling monetary policy (Costa Storti \& De Grauwe, 2001)
Financial Technology has changed the payment system in society and has helped many companies to reduce their high capital and operating costs. FinTech is also able to replace the role of formal financial institutions such as banks in terms of payment systems, among others; Provide a market for business actors Become a means of payment Settlement clearing Assist in the implementation of more efficient investments Minimize risk from conventional payment systems Assist parties in need to save, borrow funds and equity participation

\subsection{Interest Rate}

The interest rate according to classical theory is divided into two, namely the nominal interest rate and the real interest rate. Where the nominal interest rate has a very important role in financial developments because the nominal interest rate is a determinant in increasing real interest rates. If the government does not set a ceiling on the nominal interest rate, the nominal interest rate will tend to adjust to the movement of inflation. However, with a nominal interest rate ceiling, the nominal interest rate can be less than inflation, so creating a small real interest rate reduces the amount of savings in the economy. A small interest rate will increase investment, where investment will affect the increase in income.

Demand The amount of goods depends on the interest rate, where the interest rate is an indicator of investment financing. Healthy investment will increase the amount of production of goods and services so that it will increase future income. Mobile phones, Internet technology, Litecoin, and Ethereum have a very strong relationship to Financial Technology and real interest rates, GDP, inflation, financial development indices, and stock market indices (Mumtaz, 2020)

\subsection{Exchange Rate}

The nominal exchange rate is a rate at which a person can trade the currency of one country for another country's currency. If a currency appreciates, it is said that it is strengthening, because it can buy more foreign currency. Similarly, when a currency depreciates, it is said that the currency is weakening. While the real exchange rate is a value where a person can trade goods and services from one country with goods and services from other countries (Mankiw Gregory, 2000

\section{Equations and mathematics}

\subsection{Conceptual Framework}

This study uses a quantitative approach, where the approach has been determined previously using secondary data and data in numeric form. Connecting variables in problems and hypotheses. Quantitative data, namely data in the form of numbers or qualitative data that is numbered (Sugiyono, 2014). Secondary data with the type of time series (time series) in the period 2004 2019 quarterly. Data collection methods in this study are secondary data collection obtained from Bank 
Indonesia, the internet, BPS (Central Statistics Agency), Data Words, Infokom and library techniques, are by collecting data from books, journals, and research results as well as reading sources or writing materials. relevant to this article.

Data processing using eviews 10 . The data analysis method carried out in this study will use regression equation using the least squares regression method or Ordinary Least Square (OLS)

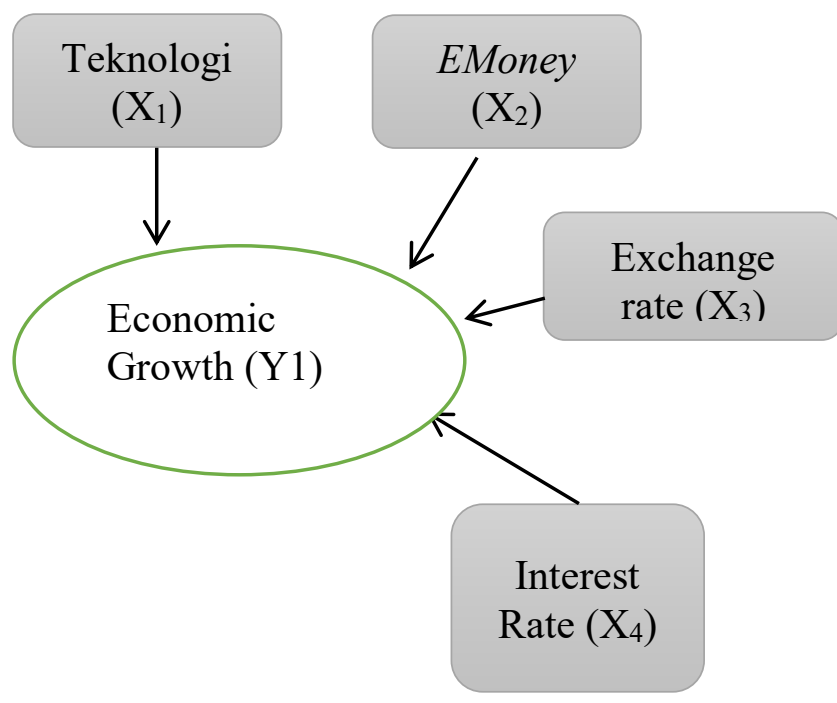

Figure 1 Conceptual Framework

\subsection{Growth Economy Equation}

$$
\begin{array}{ll}
\mathrm{Y}=\alpha_{1}+\beta_{1} \mathrm{X}_{1}+\beta_{2} \mathrm{X}_{2}+\beta_{3} \mathrm{X}_{3}+\beta_{4} \mathrm{X}_{4}+\varepsilon_{1} \\
Y_{1} & =\text { Economic Growth } \\
\mathbf{X}_{\mathbf{1}} & =\text { Technology } \\
\mathbf{X}_{2} & =\text { Emoney } \\
\mathbf{X}_{3} & =\text { Interest Rate } \\
\mathbf{X}_{4} & =\text { Exchange rate } \\
\alpha \boldsymbol{\beta} & =\text { Koefisien } \\
\boldsymbol{\varepsilon} & =\text { Error Term }
\end{array}
$$

\section{Results}

Table 4. Results

\begin{tabular}{|l|c|c|c|}
\hline Variabel & Koefisien & t-statistic & Prob \\
\hline TEK & 1.505866 & 4.245711 & 0.0001 \\
\hline EMoney & -0.335027 & -4.476063 & 0.0000 \\
\hline IR & -0.050739 & -1.218920 & 0.2277 \\
\hline ER & -2.105060 & -4.815125 & 0.0000 \\
\hline $\begin{array}{l}\text { R- } \\
\text { Squared }\end{array}$ & 0.414369 & & \\
\hline Prob>F & 0.000000 & & \\
\hline
\end{tabular}

$\mathrm{Y}=7.80 \quad-0.335^{*} \mathrm{EMONEY}+$

\section{$1.505 *$ TECHNOLOGY - $0.05 *$ IR $-2.1 *$ ER (4.4)}

The estimation results find that simultaneously or together have an effect on Economic Growth, this can be seen from Prob $F$ which is smaller than 5\%. The goodness of fit test (R2) Based on the estimation results, the inflation equation model obtained a coefficient of determination (R2) of $41.4 \%$, meaning that variations in money, exchange rate interest rates, inflation and economic growth were $41.4 \%$, while the remaining $58.6 \%$ was influenced by various factors. other. This shows that Economic Growth is not only influenced by Technology, Money, Interest Rates, Exchange Rates, but there are other factors not discussed in this study that affect Economic Growth.

\section{Discussion}

\subsection{The effect of money on economic growth}

Emoney's research results have a negative and significant effect on Economic Growth. Does not fit the hypothesis. This means that if Emoney transactions increase, economic growth will decrease. Emoney is Electronic Money used in transactions through electronic devices and also the internet network. It is very easy to use and can save costs. Increasing Electronic Money will reduce the workforce and what is left is only an educated and skilled workforce in following the development of the technology. Because all transactions use the system through technology. As a result, a reduced workforce will reduce economic growth. The use of online purchase transactions grew in 2019 by $96 \%$, previously in 2018 by $53.4 \%$ and 2017 by $32.19 \%$. The rise of digital money issuance, has not been directly proportional to the current digital innovation players. Because there are still many Indonesian people who do not understand emoney. So that this digital payment is widely used by millennial children who are generally students and still do not have a steady income. And innovation actors who do not understand the use of the E-Wallet and generally Indonesian people still like to use cash. Factors that cause economic growth that is not immobile are human resources that are not optimal, limited natural resources, lack of knowledge and technology, lack of capital and bad public attitudes

Schumpeter's Theory of Economic Growth (1934) the economic progress of a society can only be applied to entrepreneurs who have innovation and an entrepreneurial spirit and says that technological progress is largely determined by those who have an entrepreneurial spirit who are able to see opportunities and take risks.

Pitriani Ritonga (2018) Emoney has an insignificant positive effect on economic growth

Nizar, Sholeh (2021) show that the digital economy has business resilience and is significantly able to make a positive contribution to economic growth.

\subsection{The Effect of Technology on Economic Growth}

The results of the study found that technology has a positive and significant effect on economic growth. according to the hypothesis. This means that the more people use technology, the more economic growth will grow. This is because Indonesia has shown rapid 
development in the last five years. Not only by households but also by industry. And Indonesia has started to become the largest digital economy growth and development magnet in Southeast Asia and at the global level

To overcome these technological developments, the Government has prepared policies that are able to optimize the impact and results of implementing technological advances in Indonesia. namely, improving the quality of digital services to increase the efficiency and competitiveness of the sector driving Indonesia's economic growth and improving the quality of human resources (HR) so that they can adapt to future employment needs

Sollow's theory (1956) states that the higher a person's education, it is expected that the stock of human capital will be higher, because humans have a positive relationship with economic growth. Sollow theory states that Encouraging technological progress will increase income per labor market so that the opportunity to innovate in the private sector will have a major impact on economic growth. And according to Sollow, technology is an exogenous variable, while human capital is a factor that influences technology. Because capital per worker will only make a small contribution to output.

Romer's (1997) economic growth states that technological change is endogenous growth, namely technology is a process of economic growth. Meanwhile, human capital, investment, savings and physical capital also determine economic growth. According to Romer, technology is considered an endogenous factor that can have a large effect or impact on human capital who has broad insight, higher education and who has professional training so that it will create a digital financial system industry that affects economic growth aimed at the welfare of the Indonesian people.

William Straus and Neil Howe (2012) Generation Y prefers non-cash payments and non-cash payments will replace cash and tend to use technology in their work.

Raef Bahrini, et al (2019) in the Middle East and Africa technologies such as cell phones, internet users and broadband are the main drivers of economic growth and increasing human resource allocation.

Edna Meyen et al (2020) in Africa the use of technology and information stimulates the economy and creates jobs

Rinaldo Evangelista, et al (2014) in Europe digitalization can boost job productivity and have a positive effect on economic growth.

Garces \& Daim (2012) in America Technological and HR innovation has a positive effect on economic growth.

\subsection{The Effect of Interest Rate and exchange rate on Economic Growth}

The results of this study found that interest rates have a negative and insignificant effect on economic growth. In accordance with the theory and previous research. This happens because high interest rates will cause banks to withdraw money and this will cause inflation. High inflation will cause a decline in economic growth.
And high loan interest rates will reduce investors to invest because economic activity will weaken and cause economic growth to decline

The results of the study found that the exchange rate was negatively and significantly related to economic growth. In accordance with theory and research. This means that if the exchange rate of the rupiah against the dollar increases, economic growth will decrease. This is due to many factors that made the rupiah weaken because the dollar was one of the first by the American central bank to raise the benchmark interest rate as a result the dollar interest rate rose. Both demand for the dollar rose. Third, the maturity of foreign debt payments. Fourth, consumption imports increase and so on

Keynes's theory concludes that what increases GDP is an increase in consumption, investment, government spending and net exports. These four factors are again influenced by various factors, namely income, price level, interest rate, inflation rate, money supply, exchange rate.

Susanto's research (2017) finds that interest rates and exchange rates have a negative and significant effect on economic growth.

Heri Sasono's research (2020) which found that interest rates and exchange rates have a negative and insignificant effect on economic growth

\section{Conclusion}

Emoney has a negative and significant effect on economic growth, interest rates have a negative and insignificant effect on economic growth, the exchange rate has a negative and significant effect on economic growth, and technology has a positive and significant effect on economic growth

\section{References}

1. Ariff, M., Chung, T. F., \& M., S, (2012). Money supply, interest rate, liquidity and share prices: A test of their linkage. GFJ, 10 (2012)

2. Ferguson, K. K., Soutter, L., \& Neubert, M, (2019). Digital payments in Africa - how demand, technology, and regulation disrupt digital payment systems. International Journal of Teaching and Case Studies, IJTS, (2019)

3. Heri. Sasono, (2019). Analisa Pengaruh Tingkat Suku Bunga, Nilai Tukar, Inflasi, Harga Minyak Dunia, Indeks Harga Saham Gabungan Dan Produk Domestik Bruto Terhadap Pertumbuhan Ekonomi, Trijunal, (2019)

4. Khiewngamdee, C., \& Yan, H. D, (2019). The role of Financial Technologie e-payment on APEC economic development., In Conference Series, JOP, (2019)

5. McKinsey \& Company. (2020). McKinsey on Climate Change. McKinsey on Climate Change 
6. Mumtaz, M. Z., \& Smith, Z. A. (2020), Empirical examination of the role of Financial Technologie in monetary policy. PER, (2020)

7. Nampewo, D., \& Opolot, J. (2016), Financial Innovations and Money Velocity in Uganda, ADR, (2016)

8. Ningsih, S., \& Kristiyatnti, L. (2016), Analisis Pengaruh Jumlah Uang Beredar, Suku Bunga, Dan Nilai Tukar Terhadap Inflasi Di Inodnesia Periode 2014-2016, JEMSD, (2016).

9. Nizar, N. I., \& Sholeh, A. N. (2021), Peran Ekonomi Digital Terhadap Ketahanan dan Pertumbuhan Ekonomi Selama Pandemi COVID-19, JMIPTH, (2021)

10. Rodoni, A., Mufraini, A., \& Ansori, R. (2010). Analisis Pengaruh Tingkat Inflasi, Sbi, Jumlah Uang Beredar, Dan Tingkat Pendapatan Terhadap Nilai Tukar Rupiah Terhadap Dollar Amerika.

11. Sadigov, S., Vasilyeva, T., \& Rubanov, P. (2020), Financial technologie in economic growth: crosscountry analysis. In Prceeding 55 Th International Scientific Conference on Economic and Social Development-Baku, (2020)

12. Susanto (2017), Pengaruh inflasi, tingkat suku bunga, dan nilai tukar terhadap pertumbuhan ekonomi indonesia. JSTIB, (2017)

13. Vovchenko, N. G., Galazova, S. S., Sopchenko, A. A., \& Dzhu, O. S, (2019). Financial Technologie ecosystem as an instrument of sustainable development provision. IJOEBA, (2019)

14. Zhang, L., \& Ma, Q. (2011), The Effect of New Electronic Money on Money Supply. IEEE AIMSEC, (2011) 